\title{
Dendritic cell-based vaccination in metastatic melanoma patients: Phase II clinical trial
}

\author{
CHIE OSHITA $^{1}$, MASAKO TAKIKAWA ${ }^{1}$, AKIKO KUME ${ }^{1}$, HARUO MIYATA ${ }^{1}$, TADASHI ASHIZAWA ${ }^{1}$, \\ AKIRA IIZUKA $^{1}$, YOSHIO KIYOHARA ${ }^{2}$, SHUSUKE YOSHIKAWA $^{2}$, RYUJI TANOSAKI ${ }^{3}$, \\ NAOYA YAMAZAKI ${ }^{4}$, AKIFUMI YAMAMOTO ${ }^{5}$, KAZUTOH TAKESAKO $^{6}$, \\ $\mathrm{KEN} \mathrm{YAMAGUCHI}^{1}$ and YASUTO AKIYAMA ${ }^{1}$ \\ ${ }^{1}$ Division of Immunotherapy, Shizuoka Cancer Center Research Institute and ${ }^{2}$ Department of Dermatology, \\ Shizuoka Cancer Center Hospital, Shizuoka 411-8777; ${ }^{3}$ Division of Pathology and Clinical Laboratory of Medicine, \\ ${ }^{4}$ Department of Dermatology, National Cancer Center Hospital, Tokyo 104-0045; ${ }^{5}$ Department of Dermatology, \\ Saitama Medical University, Saitama 350-0495; ${ }^{6}$ Biotechnology Research Laboratories, \\ Takara Bio Inc., Ltd., Shiga 520-2193, Japan
}

Received April 30, 2012; Accepted June 12, 2012

DOI: $10.3892 /$ or.2012.1956

\begin{abstract}
Metastatic and chemoresistant melanoma can be a good target of immunotherapy because it is an intractable cancer with a very poor prognosis. Previously, we tested a dendritic cell (DC)-based phase I vaccine, and confirmed that it was safe. In the present study, we performed a phase II trial of a DC vaccine for metastatic melanoma patients with mainly the HLA-A24 genotype, and investigated the efficacy of the vaccine. Twenty-four patients with metastatic melanoma were enrolled into a phase II study of DC-based immunotherapy. The group included 19 HLA-A24-positive (A*2402) patients and 3 HLA-A2-positive (A*0201) patients. The protocol for DC production was similar to that in the phase I trial. Briefly, a cocktail of 5 melanoma-associated synthetic peptides (gp100, tyrosinase, MAGE-A2, MAGE-A3 and MART-1 or MAGE-A1) restricted to HLA-A2 or A24 and KLH were used for DC pulsing. Finally, DCs were injected subcutaneously (s.c.)
\end{abstract}

Correspondence to: Dr Yasuto Akiyama, Division of Immunotherapy, Shizuoka Cancer Center Research Institute, 1007 Shimonagakubo, Nagaizumi-cho, Sunto-gun, Shizuoka 411-8777, Japan

E-mail: y.akiyama@scchr.jp

Abbreviations: DC, dendritic cell; HLA, human leukocyte antigen; FDA, food and drug administration; IRB, institutional review board; GM-CSF, granulocyte macrophage-colony-stimulating factor; IL, interleukin; KLH, Keyhole limpet hemocyanin; IHC, immunohistochemistry; CTL, cytotoxic T cell; DTH, delayed-type hypersensitivity; $\mathrm{CR}$, complete remission; $\mathrm{PR}$, partial remission; $\mathrm{SD}$, stable disease; PD, progressive disease; ELISA, enzyme-linked immunosorbent assay; IFN, interferon; HRP, horseradish peroxydase; PS, performance status; PBMC, peripheral blood mononuclear cell

Key words: dendritic cell, immunotherapy, metastatic melanoma, HLA-A24, overall survival into the inguinal region in the dose range of $1-5 \times 10^{7}$ per shot. The DC ratio (lin-HLA-DR ${ }^{+}$) of the vaccine was $38.1 \pm 13.3 \%$ and the frequency of $\mathrm{CD}^{2} 3^{+} \mathrm{DCs}$ was $25.7 \pm 20.8 \%$. Other parameters regarding DC processing were not different from phase I. Immune response-related parameters including the ELISPOT assay, DTH reaction to peptide or KLH, DC injection numbers were shown to be related to a good prognosis. The ELISPOT reaction was positive in $75 \%$ of the patients vaccinated. The increase of anti-melanoma antigen antibody titer before vaccination was also shown to be a prognosis factor, but that post-vaccination was not. Based on immunohistochemical analysis, CD8 and IL-17 were not involved in the prognosis. Adverse effects of more than grade III were not seen. Overall survival analysis revealed a significant survival prolongation effect in DC-given melanoma patients. These results suggest that peptide cocktail-treated DC vaccines may be a safe and effective therapy against metastatic melanoma in terms of prolongation of overall survival time.

\section{Introduction}

Metastatic and chemoresistant melanoma remains intractable and very difficult to treat. Based on the remarkable antitumor efficacy of dendritic cell (DC)-based vaccines in animal experiments $(1,2)$, clinical trials of a DC-based immunotherapeutic approach have been conducted against mainly human leukocyte antigen (HLA)-A2 ${ }^{+}$advanced melanomas in Western counties (3-9). Since Nestle et al (3) first reported the efficacy of a DC vaccine against metastatic melanoma in a clinical trial, DC vaccines have become one of the main investigational therapeutic approaches against solid tumors. With regard to metastatic melanoma, it can be summarized that $\mathrm{DC}$ vaccine showed good safety and a low clinical response, but did not indicate a clear overall survival benefit (10-12). Moderate achievements were obtained in a phase I-II study, however unfortunately government-approved melanoma vaccines have yet to be developed because of the shortage of enrolled cases 
and a lack of double-blind, randomized (placebo-controlled) phase III trials.

Since sipuleucel-T (Provenge, Dendreon), an autologous cellular immunotherapy, was approved by the USA Food and Drug Administration (FDA), a significant benefit of DC-based vaccines on overall survival in metastatic castration-resistant prostate cancer patients had attracted much attention despite a low rate of clinical response (13-15). Like previous DC vaccine studies, in early phase trials, sipuleucel-T showed high safety, but a weak antitumor response which was not impressive compared with chemotherapeutic regimens. However, the last double-blind, placebo-controlled, multicenter phase III trial of the sipuleucel-T vaccine clearly demonstrated a significant survival benefit for metastatic prostate cancer.

Previously, we reported a phase I clinical trial of a DC-based vaccine against HLA-A $24^{+}$metastatic melanoma, and obtained several clinical responders (16). Based on these promising results, we have performed a phase II trial enrolling 24 metastatic melanoma patients. We summarize the results of a phase II non-randomized clinical trial and analyze various prognostic factors linked to an increase in overall survival.

\section{Materials and methods}

Patients and study design. Twenty-four patients with metastatic melanomas were enrolled in a phase II clinical trial of a peptide cocktail-pulsed DC-based vaccine from 2004 to 2010 approved by the Institutional Review Board (IRB) of Shizuoka Cancer Center, Japan. All patients gave written informed consent. Eligibility and exclusion criteria were similar to those for the previous phase I trial (16). The patients received the vaccine subcutaneously (s.c.) every week for 4 weeks, then once 2 weeks later and every month for 5 months. DCs were injected in the dose range of $1-5 \times 10^{7} /$ body/shot. Clinical response was rated as maximal through the DC vaccinations. The patients received up to 10 injections on the condition that one or more measurable lesion showed at lease a stable disease (SD) response and/or that an ELISPOT assay performed after 4 injections indicated a positive response against $>1$ melanoma-associated peptide. Adverse effects were evaluated according to the NCI Common toxicity criteria. Measurable lesions and clinical responses were evaluated by RECIST (17).

With regard to overall survival, as a retrospective control, survival data from 37 patients with metastatic melanoma given best supportive care without a DC vaccine from 2004 to 2008 were utilized with approval by the IRB of Shizuoka Cancer Center.

Preparation of the DC vaccine. The methods used to produce the DC vaccine were described previously (16). Briefly, monocyte-enriched fractions were separated from leukapheresis products using OptiPrep ${ }^{\mathrm{TM}}$, and cultured in the presence of granulocyte macrophage-colony-stimulating factor (GM-CSF) and interleukin (IL)-4 in X-VIVO15 serum-free medium. After 7 days, harvested cells were pulsed with a cocktail of 5 melanoma-specific synthetic peptides restricted to HLA-A2 or A24 and keyhole limpet hemocyanin (KLH). DC-enriched cells were washed and cryopreserved in a Cryocyte bag until used. The following peptides restricted to HLA-A2 or A24 were synthesized according to good manufacturing practice (GMP)
Table I. Characteristics of metastatic melanoma patients in the phase II study.

$\begin{array}{lr}\text { Total no. enrolled } & 24 \\ \text { Age } & 58.2 \pm 1 \\ \text { Gender } & \\ \text { M } & 12 \\ \text { F } & 12 \\ \text { Performance status } & \\ \text { PS0 } & 22 \\ \text { PS1 } & 2 \\ \text { HLA-typing } & \\ \text { A2 } & 3 \\ \text { A24 } & 21\end{array}$

Previous therapy

ST 1

CT 3

$\begin{array}{lr}\mathrm{ST}+\mathrm{CT} & 19\end{array}$

$\mathrm{ST}+\mathrm{CT}+\mathrm{RT}$

1

ST, surgical therapy; CT, chemotherapy; RT, radiation therapy.

standards by Multiple Peptide Systems, CA: HLA-A2: MART-1, gp100, tyrosinase, MAGE-A2, and MAGE-A3 and HLA-A24: gp100, tyrosinase, MAGE-A1, MAGE-A2 and MAGE-A3.

Characterization of tumor specimens using RT-PCR and immunohistochemistry. Specimens of primary tumors or skin metastatic lesions were obtained from 12 patients in a phase II study. The expression of melanoma tumor antigens was investigated using RT-PCR. HLA-class I protein expression and the phenotypes of lymphocytes infiltrating the tumor site were examined using immunohistochemistry (IHC). The monoclonal antibodies (mAbs) against human HLA-class I (Hokudo Co., Ltd., Sapporo, Japan), CD8 (Thermo Scientific, Flemont, CA), Foxp3 (Abcam, Cambridge, MA) and IL-17 (Abcam) were all purchased commercially.

Immunological monitoring. The ELISPOT assay, intracellular cytokine staining using anti-human interferon (IFN)- $\gamma$ and anti-IL-4 antibodies and delayed-type hypersensitivity (DTH) skin tests were described previously (16). Briefly, the HLA-A2 or A24 peptide cocktail solution diluted to a dose of $5 \mu \mathrm{g} / \mathrm{ml}$ and KLH were injected intradermally into the forearm for DTH measurements after $48 \mathrm{~h}$.

Serum autoantibody against melanoma antigens. The ELISA for detecting human antibodies and the control reaction system were described previously (18). MAGE antigen proteins with a glutathione S-transferase (GST) tag were all purchased from Abnova Corp., Taipei, Taiwan. Recombinant MAGE-A1 and -A2 were full-length constructs and MAGE-A3 was a fragment, comprising amino acids 1-135. Briefly, recombinant human MAGE antigens were added to a 96-well microplate, and sequentially diluted rabbit anti-human $\operatorname{IgG}$ antibody was added. After blocking with $3 \%$ bovine serum albumin (BSA), 
Table II. Phase II study of DC-based therapy against melanoma.

\begin{tabular}{|c|c|c|c|c|c|c|c|c|}
\hline \multirow[b]{2}{*}{ Case } & \multirow[b]{2}{*}{ Age } & \multirow[b]{2}{*}{ Gender } & \multirow[b]{2}{*}{ Measurable lesions } & \multirow[b]{2}{*}{ DC no. (times) } & \multirow[b]{2}{*}{ Side effects } & \multicolumn{2}{|c|}{ DTH } & \multirow[b]{2}{*}{ Response $(\mathrm{ST})^{\mathrm{a}}$} \\
\hline & & & & & & $\mathrm{DC}$ & KLH & \\
\hline MEL-1 & 53 & $\mathrm{~F}$ & Liver & $4.2 \times 10^{7}(10)$ & Fever (II) & + & + & $\mathrm{SD}(7.5)$ \\
\hline MEL-2 & 50 & $\mathrm{~F}$ & Lung & $5.2 \times 10^{7}(10)$ & ND & + & + & PD (7) \\
\hline MEL-3 & 46 & $\mathrm{~F}$ & Lung & $0.5 \times 10^{7}(11)$ & ND & + & + & $\mathrm{SD}(8.5)$ \\
\hline MEL-4 & 62 & M & Lung, liver, LN & $7.3 \times 10^{7}(8)$ & Hepatic (I) & - & + & PD (6) \\
\hline MEL-5 & 63 & M & Lung, liver & $3.1 \times 10^{7}(8)$ & Hepatic (II) & - & - & PD (6) \\
\hline MEL-6 & 45 & $\mathrm{~F}$ & Lung & $0.7 \times 10^{7}(10)$ & Leucopenia (II) & + & + & $\mathrm{SD}(30)$ \\
\hline MEL-7 & 57 & $\mathrm{~F}$ & Lung & $0.3 \times 10^{7}(10)$ & ND & - & + & PD (12) \\
\hline MEL-8 & 68 & M & Skin & $0.6 \times 10^{7}(14)$ & ND & + & + & PR (12) \\
\hline MEL-9 & 56 & M & Lung, LN & NE (15) & Hepatic (I) & + & + & $\mathrm{SD}(32)$ \\
\hline MEL-10 & 73 & $\mathrm{~F}$ & Lung, liver & $\mathrm{NE}(5)$ & ND & - & - & PD (3.5) \\
\hline MEL-11 & 68 & $\mathrm{~F}$ & Liver, LN & NE (6) & ND & - & - & $\mathrm{PD}(5.5)$ \\
\hline MEL-12 & 53 & M & Skin, LN & NE (6) & Hepatic (II) & - & + & PD (9) \\
\hline MEL-13 & 63 & $\mathrm{~F}$ & Liver, LN & $0.6 \times 10^{7}(10)$ & ND & - & - & PD (12) \\
\hline MEL-14 & 73 & $\mathrm{~F}$ & Lung & $1.5 \times 10^{7}(3)$ & ND & ND & ND & PD (1.5) \\
\hline MEL-15 & 32 & M & Lung, LN & $1.0 \times 10^{7}(10)$ & ND & - & + & PD (7) \\
\hline MEL-16 & 62 & $\mathrm{~F}$ & Lung & $1.1 \times 10^{7}(8)$ & ND & - & - & PD (6) \\
\hline MEL-17 & 60 & M & Lung, LN & $1.2 \times 10^{7}(12)$ & Fever (I) & - & + & PD (10) \\
\hline MEL-18 & 82 & $\mathrm{~F}$ & Nasal cavity & $0.5 \times 10^{7}(10)$ & ND & - & - & PD (9.5) \\
\hline MEL-19 & 63 & M & Lung & $0.9 \times 10^{7}(25)$ & Hepatic (I) & + & + & SD (60) \\
\hline MEL-20 & 40 & M & Lung, bone & $1.7 \times 10^{7}(4)$ & ND & ND & ND & PD (3) \\
\hline MEL-21 & 36 & M & Lung & $1.2 \times 10^{7}(20)$ & ND & + & + & PD (46) \\
\hline MEL-22 & 63 & $\mathrm{~F}$ & $\mathrm{LN}$ & $3.9 \times 10^{7}(6)$ & ND & + & + & PD (7.5) \\
\hline MEL-23 & 70 & M & Gingiva, lung & $1.9 \times 10^{7}(20)$ & ND & - & - & SD (18.5) \\
\hline MEL-24 & 59 & M & Lung, skin & $1.5 \times 10^{7}(13)$ & ND & - & - & PD (12.5) \\
\hline
\end{tabular}

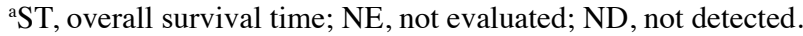

diluted patient serum (before or after vaccine) or human IgG at $100 \mu \mathrm{g} / \mathrm{ml}$ was added to antigen-coated wells or anti-human IgG-coated wells, respectively. After incubation, sheep horseHRP-conjugated anti-human IgG antibody, then substrate solution was added and the absorbance at $450 \mathrm{~nm}$ was read. A serum antibody index was calculated using the control calibration curve as follows; index $=$ [capture antibody dose $(\mu \mathrm{g} / \mathrm{ml}) /$ control OD x sample OD/dilution ratio of sera].

Statistical analysis. The overall survival of metastatic melanoma patients was examined by comparing differences in mean survival time (MST) via the Kaplan-Meier method. A comparative analysis of survival times between groups was then performed using the log-rank test. Values of $\mathrm{P}<0.05$ were considered statistically significant.

\section{Results}

Patient characteristics. Patient details are summarized in Table I. Most of the patients were in good performance status (PS), were HLA-A $24^{+}$and had received prior chemotherapy. As to the number of target lesions, half of the patients had $>2$ metastatic lesions, the average being $1.7 \pm 0.7$ (Table II).
DC processing and characterization. The mean number of peripheral blood mononuclear cells (PBMCs) collected by apheresis in phase II patients was $8.5 \pm 2.5 \times 10^{9}$. The CD14 frequency increased from $19.5 \pm 10.6$ to $44.7 \pm 15.3 \%$ after OptiPrep density-gradient centrifugation. The mean percentage of DCs rated as $\operatorname{lin}^{-} \mathrm{CD} 11 \mathrm{c}^{+} \mathrm{HLA}^{-\mathrm{DR}^{+}}$was $38.1 \pm 13.3 \%$, not different from that in the phase I trial (data not shown). The frequencies of the DC marker including CD83, CD80, CD86, DC sign, DEC205 and CMRF56, and DC1/DC2 ratio did not differ from the previous report either (data not shown).

Clinical responses and adverse effects. Among 24 cases, 1 case of partial remission (PR), 7 cases of SD and 16 cases of progressive disease (PD) were verified (Table II). The injected mean DC number was up to $5.0 \times 10^{7} /$ body at a maximum, averaging $2.4 \times 10^{7} /$ body/shot. DC injection times were 10.5 on average, and 15 cases were completed with 10 injections. No significant side effects of more than grade III were seen.

Immunological monitoring. Eighteen of 24 cases (75\%) showed positive ELISPOT reactions against all melanoma antigenrelated peptides (Table III). Six exhibited reaction against $>3$ peptides. As to the Th1/Th2 balance after vaccines, 12 of 19 
Table III. Immunological monitoring in melanoma patients (phase II).

\begin{tabular}{|c|c|c|c|c|c|c|}
\hline Case & $\begin{array}{l}\text { HLA } \\
\text { typing }\end{array}$ & $\begin{array}{c}\text { Tumor antigen } \\
\text { expression }^{\mathrm{a}}\end{array}$ & $\begin{array}{l}\text { HLA-class I } \\
\text { expression }\end{array}$ & $\begin{array}{l}\mathrm{DC} 1 / \mathrm{DC} 2 \\
\text { ratio }\end{array}$ & ELISPOT & $\begin{array}{l}\text { Th1/Th2 } \\
\text { balance }^{\mathrm{b}}\end{array}$ \\
\hline MEL-1 & $\mathrm{A}^{*} 2402$ & ND & ND & 192 & 1 (MAGE1) & 1.24 \\
\hline MEL-2 & $A^{*} 2404$ & $5 / 5$ & + to ++ & 7.6 & 0 & $\mathrm{NE}$ \\
\hline MEL-3 & A*2402 & ND & ND & 149 & 3 (MAGE1-3) & 1.3 \\
\hline MEL-4 & A*2402 & $2 / 5$ & + to ++ & 45.4 & 1 (Tyr) & 0.83 \\
\hline MEL-5 & $A^{*} 2420$ & ND & ND & 13.8 & 0 & 0.91 \\
\hline MEL-6 & A*2402 & $2 / 5$ & ++ & 104 & 3 (MAGE1-3) & 1.12 \\
\hline MEL-7 & A*2402 & $4 / 5$ & ++ & 125 & 3 (MAGE1-3) & 1 \\
\hline MEL-8 & A*2402 & $4 / 5$ & ++ to +++ & 435 & $2(\mathrm{MAGE} 1,2)$ & $\mathrm{NE}$ \\
\hline MEL-9 & $\mathrm{A}^{*} 0201$ & ND & ND & 18.1 & 0 & 1.36 \\
\hline MEL-10 & A*2402 & $3 / 5$ & + & 103 & $2($ MAGE1,2) & 1.25 \\
\hline MEL-11 & $A^{*} 2402$ & $3 / 5$ & + & 24.1 & 2 (MAGE1,2) & 0.79 \\
\hline MEL-12 & A*2402 & ND & ++ to +++ & 35.0 & 1 (MAGE3) & 1.17 \\
\hline MEL-13 & A*2402 & ND & ND & 78.0 & 0 & 0.67 \\
\hline MEL-14 & A*2402 & $5 / 5$ & + & 8.8 & 0 & ND \\
\hline MEL-15 & $A^{*} 2402$ & $3 / 5$ & ++ & 7.2 & 4 (MAGE1-3,Tyr) & 0.46 \\
\hline MEL-16 & A*0201 & ND & ND & 10.4 & 1 (MAGE2) & 1.25 \\
\hline MEL-17 & A*0201 & $5 / 5$ & + & 34.0 & 2 (gp100,MAGE2) & 1.01 \\
\hline MEL-18 & A*2402 & ND & ND & 28.6 & 3 (MAGE1-3) & 1.45 \\
\hline MEL-19 & A*2402 & ND & ND & 12.6 & 3 (MAGE1-3) & 1.69 \\
\hline MEL-20 & A*2402 & ND & ND & 73.8 & ND & ND \\
\hline MEL-21 & A*2402 & ND & ND & 127 & $2(\mathrm{MAGE} 1,2)$ & 0.36 \\
\hline MEL-22 & $A^{*} 2402$ & $4 / 5$ & + & 16.3 & 1 (MAGE3) & ND \\
\hline MEL-23 & A*2402 & ND & ND & 2.2 & 2 (Tyr,MAGE3) & 0.81 \\
\hline MEL-24 & A*2402 & $2 / 5$ & + & 6.3 & 1 (MAGE3) & 1.81 \\
\hline
\end{tabular}

${ }^{\mathrm{a}}$ No. of positive antigens of 5 melanoma antigens (tyrosinase, gp100, MAGE1, 2, 3). ${ }^{\mathrm{b}} \mathrm{Th} 1 / \mathrm{Th} 2$ balance shows the ratio of post-/pre-vaccineTh1/Th2. NE, not evaluated; ND, not done.

evaluable cases had a ratio of $>1$, which indicated a shift to Th1 development. With regard to skin tests, DTH reactions against peptide-pulsed DC and KLH were detected in 41 and 64\%, respectively, of vaccinated patients (Table II).

Serum antibodies against melanoma antigens. Prior to DC vaccines, positive cases of anti-MAGE-A1, -A2, -A 3 and tyrosinase antibodies numbered $15,10,1$ and 9 , respectively among 31 evaluable cases from the phase I and II trials. The positive rate of anti-melanoma antigens antibody was $54.8 \%$ (Fig. 1, Table IV). On the other hand, the positive rate of any antibody after vaccination was not high $(40.7 \%)$ compared with before the vaccine. The index ratio means the Ab index after vaccine/before vaccine.

Characterization of tumor tissues. IHC was performed using tumor tissue sections derived from 22 melanoma patients of phase I and II trials. Fifteen tumor tissues in which melanoma antigen expression was analyzed using RT-PCR, showed $>2$ antigens (Table III, phase I data not shown). Meanwhile, IHC analysis demonstrated that most $(82 \%)$ of the 22 evaluable tumor tissue specimens showed HLA-class I expression, and that CD8 and IL-17 positive staining was seen in $60 \%$ and $53 \%$, respectively (Table V, Fig. 2).
Overall survival analysis. Based on survival data from all metastatic melanoma patients including these of the phase I and II study, various clinical, immunological and DC-processingrelated parameters were analyzed in terms of the relationship to the prognosis of melanoma patients.

First of all, overall survival analyses were performed between the vaccinated and non-vaccinated patients, and between high $(\geq 2)$ and low $(<2)$ ELISPOT score groups (Fig. 3). The ELISPOT score indicates the number of peptides with a positive cytotoxic T-cell (CTL) response. The vaccinated group and ELISPOT high score group demonstrated significantly longer mean survival times (13.6 M in vaccinate vs. 7.3 $\mathrm{M}$ in non-vaccinated; $21.9 \mathrm{M}$ in high ELISPOT score vs. 8.1 $\mathrm{M}$ in low).

Second, DC processing-related parameters including injected DC numbers, DC ratio, and surface markers such as CD83 and CCR7 did not demonstrate any relationship to overall survival (Table VI). Third, various immunological parameters were analyzed in terms of survival prolongating effects (Table VII). The number of target lesions and the number of DC injections showed a significant correlation with survival time. Interestingly, the anti-MAGE-A1 antibody titer before the vaccination was shown to be a good prognostic 

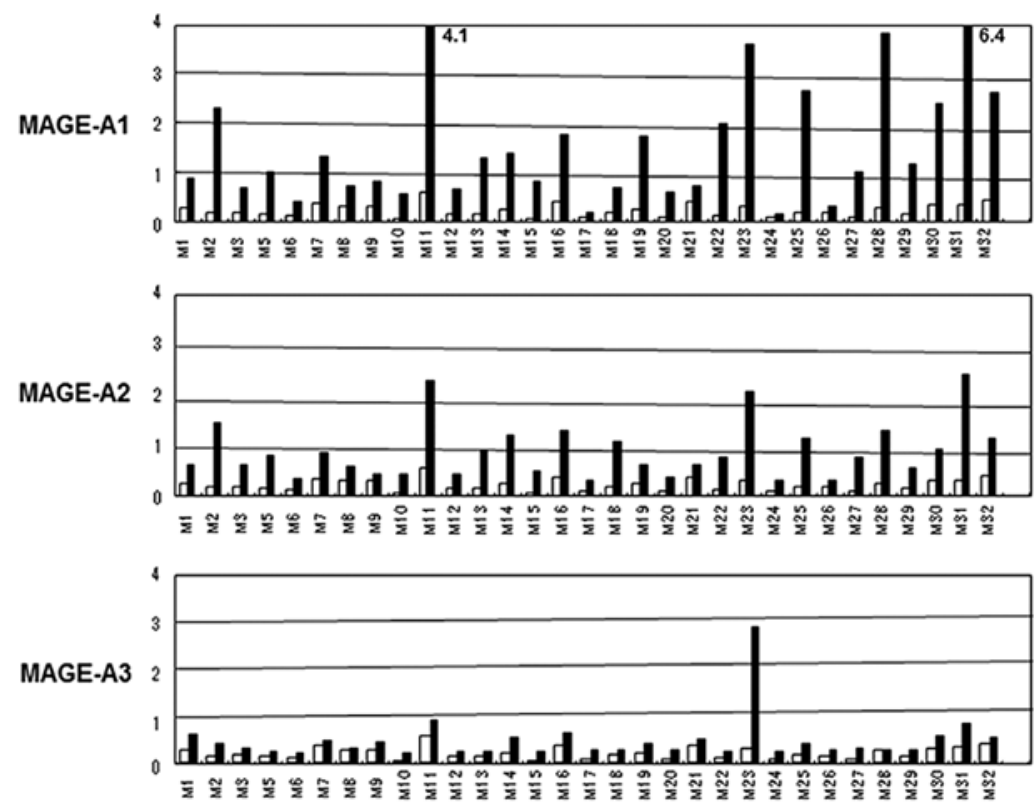

Figure 1. Serum autoantibody against MAGE antigens in melanoma patients before the vaccination. Sera derived from 31 evaluable cases in the phase I and II trials were analyzed. The ELISA for human antibody detection and the control reaction system were described previously. Recombinant GST-tagged MAGE proteins were used as antigens. Open column, GST alone; closed column, GST-tagged MAGE proteins for antigen.

Table IV. Positive rate of serum autoantibody against melanoma antigens.

\begin{tabular}{lccccc}
\hline Antigens & MAGE-A1 & MAGE-A2 & MAGE-A3 & Tyrosinase & Any antigen \\
\hline Pre $($ Index $>1)$ & $15 / 31$ & $10 / 31$ & $1 / 31$ & $9 / 27$ & $17 / 31$ \\
Post $\left(\right.$ Index ratio $\left.{ }^{\text {a }}>2\right)$ & $4 / 19$ & $4 / 27$ & $5 / 25$ & $7 / 27$ & $11 / 27$ \\
\hline
\end{tabular}

andex ratio means the antibody index after/before vaccine for melanoma antigens.

Table V. Immunohistochemical features of melanomas: phase I, II study.

\begin{tabular}{lcccc}
\hline Antigens & HLA-class I & CD8 & Foxp3 & IL-17 \\
\hline $\begin{array}{l}\text { Melanoma } \\
\text { tumors } \\
(\text { positive \%) }\end{array}$ & $18 / 22(82)$ & $9 / 15(60)$ & $4 / 15(27)$ & $8 / 15(53)$ \\
\hline
\end{tabular}

factor, but anti-melanoma antigen antibody induction after vaccination was not. Immune response parameters such as ELISPOT, DTH reaction against peptide and KLH also showed a significant survival benefit. However, IHC para-meters such as CD8 and IL-17 stain levels were not relevant to survival possibly due to the shortage of case numbers where a tumor specimen was obtained.

\section{Discussion}

Many clinical trials of immunotherapy using DC-based vaccines against metastatic melanoma have been performed, since Nestle et al (3) reported the efficacy of a melanoma
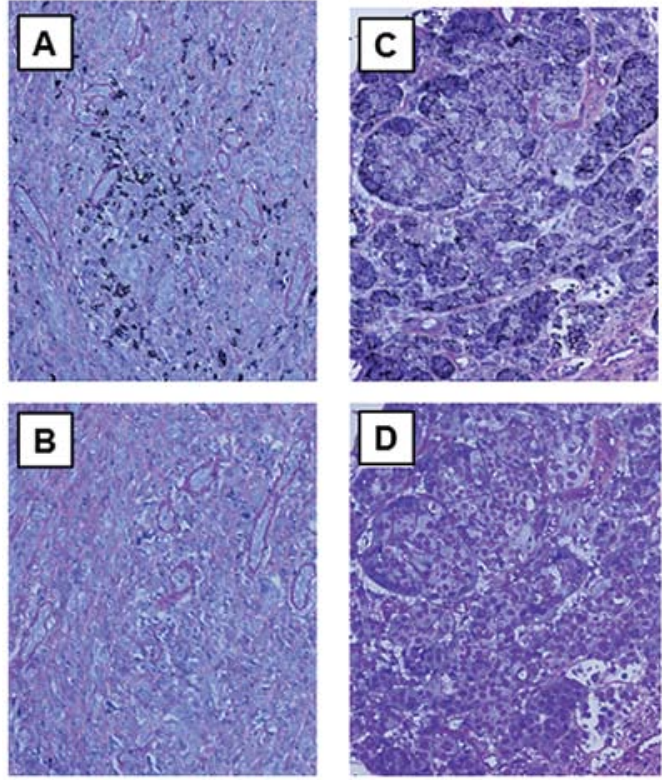

Figure 2. Immunohistochemical analysis of CD8 and IL-17 expression in melanoma tumors. (A) and (B) tumor tissue from MEL-2; (C) and (D) tumor tissue from MEL-11. (A) CD8 staining, (C) IL-17 staining, (B) and (D) isotype control antibody staining. The counter-staining was performed with the Giemsa stain. Magnification, x100. 

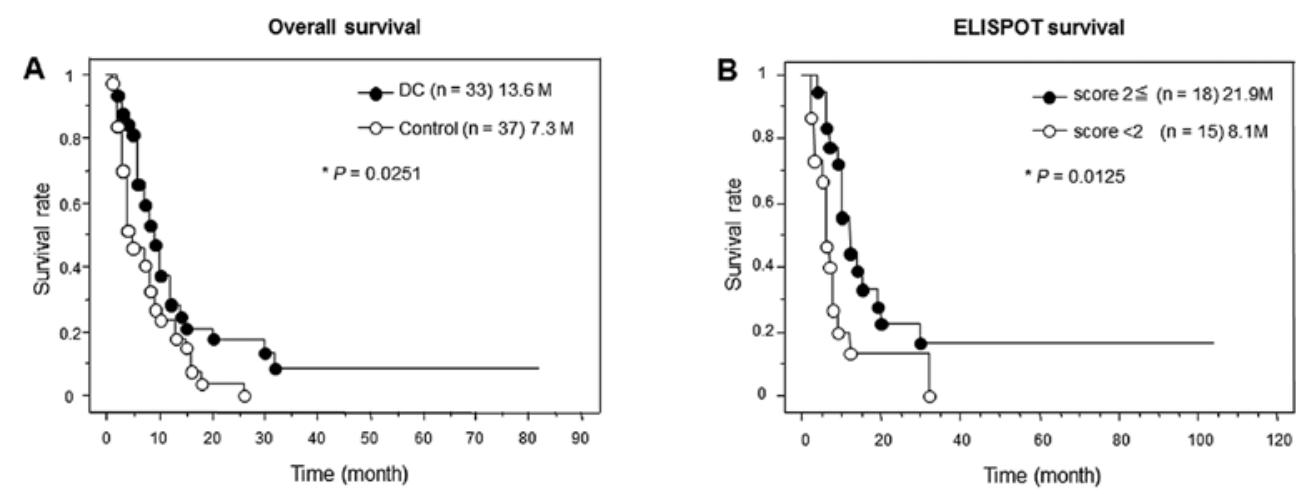

Figure 3. Survival time in melanoma patients given the DC vaccine Thirty-three metastatic melanoma patients enrolled in phase I-II trials were analyzed. Survival data derived from 37 cases of melanoma given best supportive care without DC vaccine were utilized as a control. (A) Survival analysis of melanoma patients with and without the DC vaccine. $\bigcirc$, without DC $(n=37)$; $\bullet$, with DC $(n=33)$. (B) Survival analysis for high $(\geq 2)$ and low $(<2)$ ELISPOT scores. $\bigcirc$, score $<2(\mathrm{n}=15) ; \bullet$, score $\geq 2(\mathrm{n}=18)$. The difference was analyzed using the log-rank test. Values of $\mathrm{P}<0.05$ were considered statistically significant.

Table VI. Prognostic factors for melanoma DC vaccines-1.

\begin{tabular}{lcccc}
\hline Factors & Cases & Mean \pm SD & Groups (MST) & Statistical analysis \\
\hline DC nos. $\left(\times 10^{7}\right)$ & 29 & $2.4 \pm 1.8$ & $<2(16.4)$ vs. $\geq 2(15.5)$ & NS \\
DC ratio $(\%)$ & 33 & $38.1 \pm 13.3$ & $<40(15.9)$ vs. $\geq 40(15.3)$ & $\mathrm{NS}$ \\
DC1/DC2 ratio & 33 & $107 \pm 129$ & $<100(12.6)$ vs. $\geq 100(20.3)$ & $\mathrm{NS}$ \\
CD40 $(\%)$ & 33 & $66.8 \pm 18.9$ & $<70(15.3)$ vs. $\geq 70(15.9)$ & $\mathrm{NS}$ \\
CD83 $(\%)$ & 33 & $25.7 \pm 20.8$ & $<25(14.5)$ vs. $\geq 25(16.9)$ & $\mathrm{NS}$ \\
CD83 ${ }^{+}$DC no. $\left(\times 10^{6}\right)$ & 33 & $5.5 \pm 6.4$ & $<5(15.4)$ vs. $\geq 5(16.8)$ & $\mathrm{NS}$ \\
CCR7 $(\%)$ & 33 & $29.1 \pm 21.8$ & $<25(14.3)$ vs. $\geq 25(17.0)$ & $\mathrm{NS}$ \\
\hline
\end{tabular}

NS, statistically not significant.

Table VII. Prognostic factors for melanoma DC vaccines-2.

\begin{tabular}{|c|c|c|c|c|}
\hline Factors & Cases & Mean \pm SD & Groups (MST) & Statistical analysis \\
\hline No. of target lesions & 33 & $1.7 \pm 0.7$ & $<2(24.1)$ vs. $\geq 2(8.6)$ & $0.029^{\mathrm{g}}$ \\
\hline No. of DC injections & 33 & $9.8 \pm 5.5$ & $<10(6.2)$ vs. $\geq 10(24.5)$ & $<0.0001^{\mathrm{h}}$ \\
\hline $\begin{array}{l}\text { Anti-melanoma } \\
\text { antigen } \mathrm{Ab}^{\mathrm{a}} \text { (Pre-DC) }\end{array}$ & 31 & $1.6 \pm 1.4^{\mathrm{b}}$ & $<1(3.8)$ vs. $\geq 1(22.9)$ & $0.002^{\mathrm{h}}$ \\
\hline $\begin{array}{l}\text { Anti-melanoma } \\
\text { antigen Ab (Post-DC) }\end{array}$ & 31 & $11 / 27^{\mathrm{c}}(35 \%)$ & neg. (16.9) vs. pos. (18.5) & NS \\
\hline ELISPOT assay & 33 & $1.5 \pm 1.1^{\mathrm{d}}$ & $<2(8.1)$ vs. $\geq 2(21.9)$ & $0.0125^{\mathrm{g}}$ \\
\hline DTH (peptide or DC) & 31 & $12 / 31^{\mathrm{e}}(39 \%)$ & neg. (8.9) vs. pos. (28.3) & $0.0105^{\mathrm{g}}$ \\
\hline DTH (KLH) & 31 & $18 / 31^{\mathrm{f}}(58 \%)$ & neg. (8.2) vs pos. (22.4) & $0.0244^{\mathrm{g}}$ \\
\hline Th1/Th2 balance & 29 & $1.2 \pm 0.6$ & $\leq 1(12.2)$ vs. $>1(24.1)$ & NS \\
\hline $\mathrm{CD}^{+} \mathrm{T}$ cell in tumors & 16 & $9 / 16(56 \%)$ & neg. (6.5) vs. pos. (10.9) & NS \\
\hline IL17 stain in tumors & 16 & $8 / 16(50 \%)$ & neg. (10.5) vs. pos. (7.5) & NS \\
\hline
\end{tabular}

${ }^{\mathrm{a}}$ Anti-MAGE-A1 Ab, ${ }^{\mathrm{b}}$ antibody index, ${ }^{\mathrm{c}}$ ratio of $\mathrm{Ab}$ index (post-DC/pre-DC) $>2$, ${ }^{\mathrm{d}}$ no. of peptide with positive response, ${ }^{\mathrm{e}}$ positive DTH for peptide or DC and ${ }^{\mathrm{f}}$ positive DTH for KLH. ${ }^{\mathrm{g}} \mathrm{P}<0.05$, ${ }^{\mathrm{h}} \mathrm{P}<0.01$. NS, not significant.

lysate or peptide-treated DC vaccine in 1998. In most trials, the number of registered cases was around 20 with mainly the HLA-A2 genotype, and only a few cases of clinical response [partial remission (PR) and complete remission (CR)] were reported. The difference of antigen source like synthetic peptide or tumor lysate and maturation status did not seem to 
be closely related to the clinical response (19). Additionally, a randomized phase III study of melanoma DC vaccines has not yet been performed based on early phase I, II studies. We have been testing a peptide-based DC vaccine against HLA-A24 metastatic melanoma in phase I and II clinical trials. The ethnicity of HLA genotyping revealed a significant difference of CTL epitope sequence and immunological responses, which suggested that HLA-A $24^{+}$-based immune response is unique and should be investigated more intensively.

In the present study, based on survival data from all metastatic melanoma patients from phase I and II trials, potential prognostic factors were investigated among various clinical, immunological and DC-processing-related parameters in terms of the prolongating effect on overall survival. Unfortunately, DC processing-related parameters did not show any effect on overall survival. Interestingly, the antiMAGE-A1 antibody titer before the vaccination was shown to be a possible prognostic factor, but anti-melanoma antigen antibody induction after the vaccination was not. Recently, an autoantibody signature-based approach has been used to discover novel tumor antigens (20-22). Especially, in melanoma patient-derived serum, novel biomarkers involved in lymph node metastasis prediction were identified (23). As to MAGE antigens, Stockert et al reported that an autoantibody against MAGE-A1 was detected in only 3 of 234 cancer patients (24), which was a very low frequency compared with ours (48.4\% in metastatic melanoma patients). Impressively, our study demonstrated that the anti-MAGE-A1 autoantibody was positively correlated with overall survival, which seems to be a novel observation. Meanwhile, the number of target lesions and immune response parameters such as ELISPOT, DTH reaction against peptide and KLH showed a prolongation effect on overall survival, which was reasonable because tumor load and immunological responses are known to be closely linked to prognosis in melanoma patients $(3,8)$.

The infiltration of $\mathrm{CD}^{+}$and $\mathrm{TH} 17$ cells at the tumor site is reported to be closely involved in the prognosis of solid cancer patients (25-27). In our study, the positive rate of CD8 and IL-17 was 60 and 53\%, respectively, in 15 resected tumors. However, a significant correlation to prognosis was not seen because of the small number of cases.

Since sipuleucel-T (Provenge) immunotherapy was approved by the FDA, DC-based cancer vaccine studies have been encouraged and enhanced to develop the advanced stage of clinical trials $(28,29)$. As is the case with sipuleucel-T, there will be some problems with DC-based cancer vaccines. One is that the time for clinical evaluation might be too short to expect prolongation of survival time because the optimal immune response would have several weeks to operate and pass the cancer progression. A conventional clinical evaluation based on RECIST criteria is incompatible with overall survival benefit obtained only by the continual administration of vaccine despite clinical progression. To define the progression precisely in prostate cancer, the Prostate Cancer Working Group recently devised progression guidelines (30).

Very recently, studies of novel cancer vaccines like sipuleucel-T and MAGE-A3 and other long peptides with conjugation were activated at subclinical levels, which demonstrates the coming of a new era for cancer vaccines (31-33). The bottom line is that sequentially to the success of sipuleucel-T trials, more phase III randomized studies of specific peptidepulsed DC vaccines should be performed. Additionally, a world-wide network of translational research facilities which can perform high-grade clinical immunotherapeutic research has to be constructed. These efforts could lead to more efficient cancer vaccines in the near future.

\section{Acknowledgements}

This study was supported by a grant from the Cooperation of Innovative Technology and Advanced Research in Evolutional Area (CITY AREA) program from the Ministry of Education, Culture, Sports, Science and Technology, Japan.

\section{References}

1. Mayordomo JI, Zorina T, Storkus WJ, Zitvogel L, Celluzzi C, Falo LD, Melief CJ, Ildstad ST, Kast WM and Deleo AB: Bone marrow-derived dendritic cells pulsed with synthetic tumor peptides elicit protective and therapeutic antitumor immunity. Nat Med 1: 1297-1302, 1995.

2. Zitvogel L, Mayordomo JI, Tjandrawan T, DeLeo AB, Clarke MR, Lotze MT and Storkus WJ: Therapy of murine tumors with tumor peptide-pulsed dendritic cells: dependence on T cells, B7 costimulation, and T helper cell 1-associated cytokines. J Exp Med 183: 87-97, 1996.

3. Nestle FO, Alijagic S, Gilliet M, Sun Y, Grabbe S, Dummer R, Burg G and Schadendorf D: Vaccination of melanoma patients with peptide- or tumor lysate-pulsed dendritic cells. Nat Med 4: 328-332, 1998.

4. Ranieri E, Kierstead LS, Zarour H, Kirkwood JM, Lotze MT, Whiteside T and Storkus WJ: Dendritic cell/peptide cancer vaccine: clinical responsiveness and epitope spreading. Immunol Invest 29: 121-125, 2000.

5. Thurner B, Haendle I, Roder C, Dieckmann D, Keikavoussi P, Jonuleit H, Bender A, Maczek C, Schreiner D, von den Driesch P, et al: Vaccination with Mage-3a1 peptide-pulsed mature, monocyte-derived dendritic cells expands specific cytotoxic T cells and induces regression of some metastases in advanced stage IV melanoma. J Exp Med 190: 1669-1678, 1999.

6. Panelli MC, Wunderlich J, Jeffries J, Wang E, Mixon A, Rosenberg SA and Marincola FM: Phase 1 study in patients with metastatic melanoma of immunization with dendritic cells presenting epitopes derived from the melanoma-associated antigens MART-1 and gp100. J Immunother 23: 487-498, 2000.

7. Jonuleit H, Giesecke-Tuettenberg A, Tuting T, Thurner-Schuler B, Stuge TB, Paragnik L, Kandemir A, Lee PP, Schuler G, Knop J and Enk AH: A comparison of two types of dendritic cell as adjuvants for the induction of melanoma-specific T-cell responses in humans following intranodal injection. Int J Cancer 93: 243-251, 2001.

8. Banchereau J,Palucka AK, Dhodapkar M, Burkeholder S, Taquet N, Rolland A, Taquet S, Coquery S, Wittkowski KM, Bhardwaj N, et al: Immune and clinical responses in patients with metastatic melanoma to $\mathrm{CD} 34^{+}$progenitor-derived dendritic cell vaccine. Cancer Res 61: 6451-6458, 2001.

9. Lau R, Wang F, Jeffery G, Marty V, Kuniyoshi J, Bade E, Ryback ME and Weber J: Phase I trial of intravenous peptidepulsed dendritic cells in patients with metastatic melanoma. $\mathrm{J}$ Immunother 24: 66-78, 2001.

10. Chakraborty NG, Sporn JR, Tortora AF, Kurtzman SH, Yamase H, Ergin MT and Mukherji B: Immunization with a tumor-celllysate-loaded autologous-antigen-presenting-cell-based vaccine in melanoma. Cancer Immunol Immunother 47: 58-64, 1998.

11. Smithers M, O'Connell K, MacFadyen S, Chambers M, Greenwood K, Boyce A, Abdul-Jabbar I, Barker K, Grimmett K, Walpole E and Thomas R: Clinical response after intradermal immature dendritic cell vaccination in metastatic melanoma is associated with immune response to particulate antigen. Cancer Immunol Immunother 52: 41-52, 2003.

12. Chang AE, Redman BG, Whitfield JR, Nickoloff BJ, Braun TM, Lee PP, Geiger JD and Mule JJ: A phase I trial of tumor-lysatepulsed dendritic cells in the treatment of advanced cancer. Clin Cancer Res 8: 1021-1032, 2002. 
13. Burch PA, Croghan GA, Gastineau DA, Jones LA, Kaur JS Kylstra JW, Richardson RL, Valone FH and Vuk-Pavlovic S: Immunotherapy (APC8015, Provenge) targeting prostatic acid phosphatase can induce durable remission of metastatic androgen-independent prostate camcer: a Phase 2 trial. Prostate 60: 197-204, 2004

14. Cheever MA and Higano CS: PROVENGE (Sipuleucel-T) in prostate cancer: the first FDA-approved therapeutic cancer vaccine. Clin Cancer Res 17: 3520-3526, 2011.

15. Kantoff PW, Higano CS, Shore ND, Berger ER, Small EJ, Penson DF, Redfern CH, Ferrari AC, Dreicer R, Sims RB, et al; IMPACT Study Investigators: Sipuleucel-T immunotherapy for castration-resistant prostate cancer. N Engl J Med 363: 411-422, 2010.

16. Akiyama Y, Tanosaki R, Inoue N, Shimada M, Hotate Y, Yamamoto A, Yamazaki N, Kawashima I, Nukaya I, Takesako K, et al: Clinical response in Japanese metastatic melanoma patients treated with peptide cocktail-pulsed dendritic cells. J Transl Med 3: 4, 2005.

17. Therasse P, Arbuck SG, Eisenhauer EA, Wanders J, Kaplan RS, Rubinstein L, Verweij J, van Glabbeke M, van Oosterom AT, Christian MC and Gwyther SG: New guidelines to evaluate the response to treatment in solid tumors. European Organization for Research and Treatment of Cancer, National Cancer Institute of the United States, National Cancer Institute of Canada. J Natl Cancer Inst 92: 205-216, 2000

18. Iizuka A, Komiyama M, Tai S, Oshita C, Kurusu A, Kume A, Ozawa K, Nakamuya Y, Ashizawa T, Yamamoto A, et al: Identification of cytomegalovirus (CMV) pp65 antigen-specific human monoclonal antibodies using single B cell-based antibody gene cloning from melanoma partients. Immunol Lett 135: 64-73, 2011.

19. Hersey P, Menzies SW, Halliday GM, Nguyen T, Farrelly ML, DeSilva $\mathrm{C}$ and Lett M: Phase I/II study of treatment with dendritic cell vaccines in patients with disseminated melanoma. Cancer Immunol Immunother 53: 125-134, 2004.

20. Desmetz C, Maudelonde T, Mange A and Solassol J: Identifying autoantibody signature in cancer: a promising challenge. Expert Rev Proteomics 6: 377-386, 2009.

21. Desmetz C, Cortijo C, Mange A and Solassol J: Humoral response to cancer as a tool for biomarker discovery. J Proteomics 72 982-988, 2009

22. Tan HT, Low J, Lim SG and Chung MC: Serum autoantibodies as biomarkers for early cancer detection. FEBS J 276: 6880-6904, 2009.

23. Liu Y, He J, Xie X, Su G, Teitz-Tennenbaum S, Sabel MS and Lubman DM: Serum autoantibody profiling using a natural glycoprotein microarray for the prognosis of early melanoma. J Proteome Res 9: 6044-6051, 2010.
24. Stockert E, Jäger E, Chen YT, Scanlan MJ, Gout I, Karbach J, Arand M, Knuth A and Old LJ: A survey of the humoral immune response of cancer patients to a panel of human tumor antigens. J Exp Med 187: 1349-1354, 1998.

25. Tosolini M, Kirilovsky A, Mlecnik B, Fredriksen T, Mauger S, Bindea G, Berger A, Bruneval P, Fridman WH, Pages F and Galon J: Clinical impact of different classes of infiltrating $\mathrm{T}$ cytotoxic and helper cells (Th1, Th2, Treg, Th17) in patients with colorectal cancer. Cancer Res 71: 1263-1271, 2011.

26. Galon J, Costes A, Sanchez-Cabo F, Kirilovsky A, Mlecnik B, Lagorce-Pages C, Tosolini M, Camus M, Berger A, Wind P, et al: Type, density, and location of immune cells within human colorectal tumors predict clinical outcome. Science 313: 1960-1964, 2006.

27. Dieu-Nosjean MC, Antoine M, Danel C, Heudes D, Wislez M, Poulot V, Rabbe N, Laurans L, Tartour E, de Chaisemartin L, et al: Long-term survival for patients with non-small cell lung cancer with intratumoral lymphoid structures. J Clin Oncol 26: 4410-4417, 2008

28. Rini BI, Weinberg V, Fong L, Conry S, Hershberg RM and Small EJ: Combination immunotherapy with prostatic acid phosphatase pulsed antigen-presenting cells (provenge) plus bevacizumab in patients with serologic progression of prostate cancer after definitive local therapy. Cancer 107: 67-74, 2006.

29. Cheever MA: Twelve immunotherapy drugs that could cure cancers. Immunol Rev 222: 357-368, 2008.

30. Scher HI, Halabi S, Tannock I, Morris M, Sternberg CN, Carducci MA, Eisenberger MA, Higano C, Bubley GJ, Dreicer R, et al; Prostate Cancer Clinical Trials Working Group: Design amd end points of clinical trials for patients with progressive prostate cancer and castrate levels of testosterone: recommendations of the Prostate Cancer Clinical Trials Working Group. J Clin Oncol 26: 1148-1159, 2008

31. Buonerba C, Ferro M and Di Lorenzo G: Sipuleucel-T for prostate cancer: the immunotherapy era has commenced. Expert Rev Anticancer Ther 11: 25-28, 2011.

32. Finke LH, Wentworth K, Blumenstein B, Rudolph NS, Levitsky H and Hoos A: Lessons from randomized phase III studies with active cancer immunotherapies-outcomes from the 2006 meeting of the Cancer Vaccine Consortium (CVC). Vaccines 25 (Suppl 2): S97-S109, 2007.

33. Tyagi P and Mirakhur B: MAGRIT: the largest-ever phase III lung cancer trial aims to establish a novel tumor-specific approach to therapy. Clin Lung Cancer 10: 371-374, 2009. 